\title{
Brain stem cells and IGF-I: implications in development, regeneration and cancer therapeutics
}

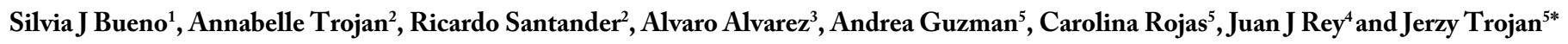 \\ ${ }^{1}$ Faculty of Health Sciences, UNAB University, Bucaramanga, Colombia \\ ${ }^{2}$ Faculty of Sciences, UNAB University, Bucaramanga, Colombia \\ ${ }^{3}$ Faculty of Medicine, University of Cartagena, Cartagena de Indias, Colombia \\ ${ }^{4}$ Faculty of Health Sciences, UNAB University, Bucaramanga, Colombia \\ ${ }^{5}$ ICGT and Lab. Legrand S.A., Bogota, Colombia, and NSERM U602, Villejuif, France
}

\begin{abstract}
For the past 40 years, our challenge has been finding a solution for the treatment of brain tumors using our knowledge of the evolution of life, the chemistry of proteins, genetics, and molecular biology. Efficient strategies were established by the construction of vectors targeting oncoproteins or growth factors (i.e. IGF-I, AFP) present during the development of the embryonic and fetal nervous system tissues originating from neural stem cells. The neoplastic stem cells, PCC 3 and PCC4, derived from mouse teratocarcinoma - tumor mimicking the structures of developing central nervous system - were transfected with the vectors expressing either antisense IGF-I RNA or IGF-I RNA forming a triple helix RNA-DNA. Both approaches completely stopped the synthesis of the IGF-I growth factor and converted the stem cells into immunogenic cells expressing MHC-I and B7. The immunogenic anti IGF-I transfected cells became antitumor vaccines. The role played by stem cells in the nervous system has motivated us in the search for knowledge focused on self-regeneration and therapeutic strategies. The strategy of Anti IGF-I vaccines was applied with success for therapy of glioblastoma.
\end{abstract}

\section{Introduction}

The brain is plastic and self-regenerative. In neurogenesis: totipotential immature cells - neural stem cells (NSC) exist in the hippocampus and ventricles, they multiply and undergo differentiation and maturation and settle in the brain site where they activate a process of multiple connections (synapses) in their new environment, a process called synaptogenesis. The stem cells of the nervous system, NSC, produce an important impact in the search for new knowledge in brain histology, physiology and pathology, including the neoplastic mechanism and anti-tumor strategy solutions [1-5].

Neurogenesis takes place in the brain when NSC generate new functional neurons and glia considering they are multipotent cells, with the ability to produce different neural lineages $[1,6]$. This process begins during foetal development and persists in adult life thanks to NSC present in the subventricular zone (SVZ) $[7,8]$ and the sub granular zone (SGZ) of the dentate gyrus of the hippocampus [9]. Neurogenesis is affected by different aspects of diet [10], exercise [11] and sleep [12] due to the association with increased production of Brain-derived neurotrophic factor (BDNF) or in the expression of genes necessary for proliferation and differentiation of NSC.

Development of NSC is related to insulin-like growth factor 1 and its receptor (IGF-1R); considering that is the convergence between an embryonic and tumor development, the IGF-I and its receptor was proposed as a target to treat the progression of the glioblastoma tumor $[13,14]$. The objective of this review is to describe the NSC in adults, as well as a relationship between IGF-I, IGF-1R and NSC implied during postnatal life development. Moreover, the use of IGF-I and IGF-IR as a target in immunogene therapy of glioblastoma will be also considered.

\section{Mother cells of the nervous system - Neural stem cells}

The studies of Ramón y Cajal surprised the world when they demonstrated for the first-time time the complexity of the microscopic neuronal components. Some of their conclusions supported the concept that we are born with a certain number of neurons that remains constant, and then many of these cells die during the course of life, due to an apoptotic process, damage to the endothelium of cerebral vessels or hyperlipidemia. The neurology studies established, for more than 100 years, the dogma that the brain of an adult remains stable, without additive changes in the number of neurons, with a power of processing and memory in irreversible involution, given by a decrease in the neuronal population over time. Humanity adapted to this concept of progressive deterioration, contributing to intellectual unproductivity. In the decade of the 90s, the advances in electron microscopy and molecular biology have changed that paradigm: the existence of totipotent stem cells (NSC) and their multiplication was demonstrated in the hippocampus and ventricles during differentiation process. Moreover, the relation between differentiation process and the growth factors responsible for neuronal maturation, self-regeneration, synaptogenesis, and cerebral plasticity. The latter allows to assume

Correspondence to: Jerzy Trojan, Professor, Faculty of Health Sciences, UNAB University, Floridablanca, and Laboratories Legrand S.A., Bogota, Colombia, Tel. 57 - 31069476 29; E-mail: genetherapy@hotmail.fr

Key words: stem cells, IGF-I, nervous system development, neoplasia, selfregeneration, therapeutic

Received: January 24, 2019; Accepted: February 13, 2019; Published: February 16, 2019 
the functions of neurons affected by injury or disease, permitting the restoration of impaired functions. A review of information on the Neural Stem Cells, NSC, is carried out since 2002 year when the paradigm of the existence and reproduction of neural stem cells is consolidated through new evidence $[15,16]$.

As far as history of nervous system description is considered, Santiago Ramon y Cajal described first the central nervous system (CNS) and neurons in details. In 1965 Altman evidenced that in adult rat's hippocampus exist neurogenesis in the granule cells zone (SGZ) of the dentate gyrus [17] , and also in the ventricular subventricular zone (V-SVZ) of the lateral ventricles $[7,18]$. The V-SVZ have 4 types of cells: type A cells are neuroblast, type B1 and B2 are astrocytes, type $\mathrm{C}$ cells are proliferative precursors, and type $\mathrm{E}$ cells are ependymal cells $[7,8]$ admitting that only type B1 have characteristics of NSC. Type $\mathrm{B} 1$ cell has end feet on blood vessels. This cell is characterized by glial markers such as glial-fibrillary acidic protein (GFAP), glutamate aspartate transporter (GLAST), and brain lipid-binding protein (BLBP) $[8,19]$. When $\mathrm{B} 1$ cells proliferate, they produce asymmetric division to produce type $C$ cells and renew themselves $[20,21]$. After production of type $\mathrm{C}$ cells, they divide again and produce neuroblast or type $\mathrm{A}$ cells. The last ones then proliferate and migrate to the rostral migratory stream (RMS), that leads to the olfactory bulb (OB) [22] where they become GABAergic inhibitory interneurons $[7,23]$.

As to the role of the dentate gyrus (DG) composed by different layers, one of them is the sub granulate zone (SBZ) where the NSC are concentrated [24]: parvalbumin - expressing interneurons regulate the states of NSC by GABAergic inputs [25], because these interneurons keep constant stimuli of GABA leading to hyperpolarization. When this impulse decrease, NSC transform themselves and become neural progenitor cells, following further transformation into granule cells and integrate the hippocampus circuitry [26]. Different factors influence neurogenesis, that leads NSCs present in the DG and SBZ to astrogliosis, neurogliosis and vascular remodelling [27-28].

The DG aging generates a more active state of NSC, but decreases the proliferation of NSCs and moreover produces in the OB a reduced response to epidermal growth factor signaling [29]. As far as decreasing of NSC is considered, in the experiment of Villeda et al., it was demonstrated that in young mice inoculated with old mice blood it exists a soluble molecule leading to decrease proliferation of NSC, for example CCL11 (also known as exotoxin) [30]. On the other side, there is also an evidence about the increase of TGF and IL-6 generating a pro-inflammatory state [30].

There are different mechanisms explaining neurogenesis and human cognitive functions including an increase in neurotrophic factors (BDNF and IGF-1) [31-33] reducing the time of cell cycle in S-phase $[34,35]$, preventing the death of new neurons or their relation with angiogenesis [36].

Among different factors affecting neurogenesis [37], the immunologic factors play an important role in development of NSC and neurogenesis during adult life, especially cytokines like interleukin-1 (IL-1) [38], tumor necrosis factor alpha (TNF- $\alpha$ ) [39], interleukin6(IL-6) [40], interferon gamma (IFN- $\gamma$ ) and leukemia inhibitory factor (LIF) [41-43]. Related to immune mechanism Insulin-like growth factor-1 (IGF-I) is a polypeptide of 70-amino-acid [44] playing a role in normal NSCs by inducing differentiation, proliferation or survival of neurons in SVZ and DG [45,46,47]. IGF-I activates genes like RIT-1 to produce Ras-related GTPase and increase proliferation of hippocampal neural stem cells (HNSCs) [48-50]. Besides that, it helps a maturation process of transformation NSCs into neurons, which are integrated in dendritic trees [51]. Moreover, it helps in the SVZ, a migration of the NSCs to the olfactory bulb $[52,53]$. Also the variants of the IGF-1 like MGF induce neurogenesis in DG and in SVZ [54].

\section{Autoregeneration of CNS}

In the 2000s, Fred H. Gage described some of the advances in neuroscience in recent years [55-57]. It was discovered that the brain changes throughout life, originating new neurons and their respective synapses with neighboring cells. Self-regeneration and plasticity allow them to repair themselves in the period after an injury or illness, and adapt to a series of circumstances in which an extra capacity is required, there being the possibility of potentiating the brain in its thinking capacity (see references below). The use of drugs that stimulate the brain to replace its own cells (neurogenesis) and reconstruct damaged neuronal circuits are new perspectives that constitute alternatives to the old use of neurotransmitters and cell transplantation in cases of Parkinson's, Huntington's or spinal cord injury, which have resulted poor. Moreover, the discovery has concerned the phenomenon of appearance of new neurons in the brains of adult birds and nonhuman primates and humans, giving the phenomenon the name of neurogenesis. They found totipotent stem cells that divide periodically, producing other stem cells, new neurons, support cells or glia, and located predictively in the ventricle, hippocampus and olfactory bulb. Whether they are neurons with their respective synapses or glial cells, depends on the site of the brain where they arrive and on their activity, that occurs at the moment of arrival. It takes 1 month, from the moment the new neuron is formed until it becomes a functional cell capable of receiving and sending information. Neurogenesis is a highly controlled complex process; the transformation of totipotent cells in neurons or glia is regulated by the action of the Neurotropic Factor of the Brain and the Factor Similar to Insulin: brain-dependent neurotropic factor (BDNF) keeps neurons alive; the ciliary neurotropic factor (CNTF) protects neurons from death; neurotropin-3 (NT-3) promotes the formation of oligodendrocytes; GDNF), potentiates the motor neurons to form new branches; epidermal growth factor, EGF, an inducer of the division of brain stem cells and fibroblast growth factor, FGF, in low doses keep alive several types of cells; Glial-2 (GGF-2) stimulates beneficial glial production; Insulin-like Growth Factor - 1, stimulates the birth of neurons and glia cells; FGF and EGF participate in the neurogenesis of the hippocampus to reconstruct the necrotic tissue after vascular accidents; FGT and presenilin increase neurogenesis in Alzheimer to reverse the disease. Fred H. Gage has proposed that the following events occur in neurogenesis: Stem cells are the source of new cells. They are periodically divided into 2 main areas: the ventricles which contain the spinal brain fluid (CSF) and the hippocampus, a crucial structure for learning new information and memory. The hippocampus, by producing new neurons, conditions the formation of connections between existing and new neurons, increasing the brain's ability to process and record

new information. The mother cells proliferate producing other daughter mother cells and neuronal precursors, which, in turn, some will become neurons but others in support cells (astrocytes andoligo dendrocytes, glial cells). The newly formed daughter stem cells move away from their progenitors and migrate to the olfactory bulb where $50 \%$ will differentiate into neuronal cells. In the adult brain, newborn neurons have been found in the hippocampus and in the olfactory bulb. Researchers are hopeful to be able to induce cerebral self-repair, stimulating the multiplication of NSCs and the synthesis of neural precursors and their subsequent maturation and specialization in 
mature neurons that establish several synapses with other neurons in a determined site, where necessary $[6,25,32,36,46,55-60]$.

\section{Stem cells, neural and glial cells in neoplasia: Therapeutic implications}

The stem cells of adult CNS can produce new neurons and cells of the glia: the embryogenic stem cells, isolated in human embryos of only 100 cells, can generate any type of cells of the body $[6,25,55,56]$. These stem cells can be cultured, multiplied and then transplanted into the Central Nervous System of an adult animal. They survive successfully in the hippocampus and olfactory bulbs and differentiate into mature neurons. If they are placed in another place they do not differentiate in neurons but in glial cells.

In 1979 , the first description of the development of the central nervous system using a new marker, alpha-fetoprotein, was made using a rat brain fetal model [61]. Using the same marker, a neoplastic model of CNS development in mouse teratocarcinoma, derived from stem cells PCC3 and PCC4, was described [62]. The comparison of the results obtained in two models, showed that there is a convergence between embryonic fetal development and neoplastic development. Is AFP a perfect antigen for targeting malignant CNS tumor?. Taking into account that AFP is present not only in glial but also in neuronal cells of differentiation, which limits its useful for differentiational diagnosis and therapy of glial and neuronal derivatived tumors. Fortunately, a new oncoprotein, the growth factor IGF-I, presented only in glial cells of normal or neoplastic development, but absent in neuronal cells, was considered for therapeutic purpose [63,64]. IGF-I is considered as the most important growth factor of normal and neoplastic development, including CNS [65]. Logically, to stop the neoplastic development, the arrest of the synthesis of IGF-I in cancer cells of glioblastoma, in the "source" at the level of transcription or translation was considered, using antisense [66-68] or triple helix $[69,70]$ technology.

The translation level of IGF-I was targeted in glioma malignant cells by antisense approach using a vector expressing antisense IGF-I RNA [64]. This technology has yielded positive results in vitro, stopping the synthesis of IGF-I in glioma cell cultures, and in vivo, stopping the neoplastic development of the tumor [71]. This strategy has given historically the birth of a new oncology domain - cancer gene therapy [72]. The injection in vivo of transfected anti - gene (antisense or triple helix) anti IGF-I cells either into animals carrying teratocarcinoma tumors derived from stem cells PCC3 and 4, or into glioma rat tumors using also transfected cells, or applied in the clinical treatment of patients with glioblastoma, has induced an antitumor immune response mediated by TCD $8+$ cells [71,73-75].

We illustrate below the efficiency of molecular biology applying anti - gene strategy targeting the IGF-I in the model of mouse teratocarcinoma derived of stem PCC3 and PCC4 embryonal carcinoma stem cells (the technique of transfection of PCC stem cells using either antisens or triple helix vectors [73,74] (Figures $1-8$ ). We need to add, that an equal to the genetically modified PCC stem cells, does not exist in nature.

The proposed mechanism of anti - gene (antisense or triple helix) therapy concerns the growths factors and their receptors (IGF-I, TGFbeta, EGF, IGF-I-R, EGF-R) - a combination of an increased antitumor immune response (CD8 + ), and an inhibition of the transduction pathway of the PI3K / AKT / GWK3 / GS signal that is involved in the transformed phenotype of the tumor [76 ]. In glioblastoma, glial tumor cells proliferate, forming rapidly growing tumors. How these cells

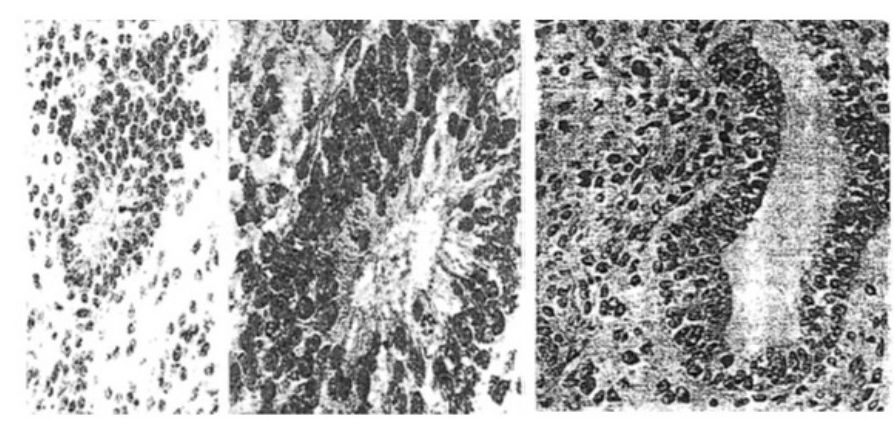

Figure 1. Teratocarcinoma structures resulted of injection into 129 mice of stem cells - PCC3 embryonal carcinoma cells. (left) Neuroepithelial rosette surrounded by neuroepithelial cells, HE, x250; (middle) Higher magnification of the same poorly differentiated neuroepithelial rosette, $\mathrm{x} 400$. (right) More advanced step of neuroepithelia differentiation showing a cyst of nervous origin "pathological neural tube". The wall of the cyst as well its neighborhood is constituted by the same type of neuroepithelial cells. Neuroepithelila cells surrounding the cyst present a character of neurospongium, HE, x 250

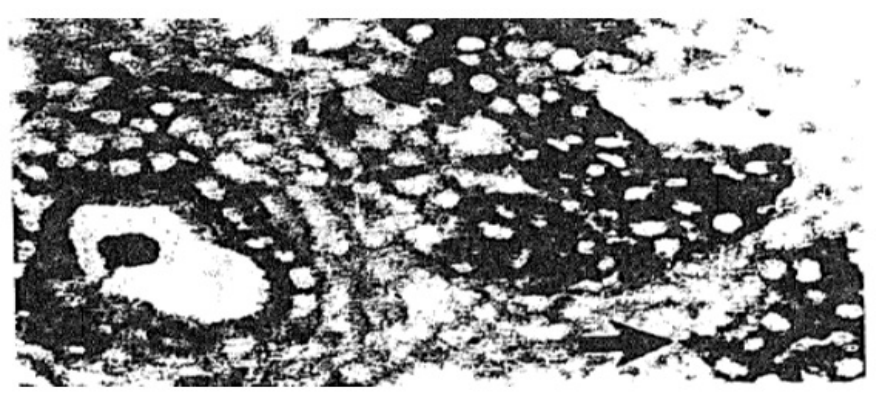

Figure 2. Teratocarcinoma resulted of injection of stem cells, PCC3 cells, showing an intermediate step of cyst differentiation (bottom down) if compared to two structures presented in figure 1. The differentiating neuroependymal tube and groups of cellas arranged in clusters (arrow) are labelled with antibodies anti AFP, Immunoperoxidase, x250.

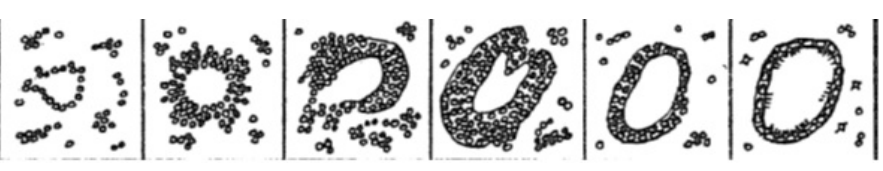

Figure 3. Teratocarcinoma resulted of injection of stem cells - PCC3 embryonal carcinom cells. Sequence of maturation of neuroepithelial structures showing steps of differentiation: 1. In differentiated; 2. Poorly differentiated (rosette); 3 . Moderately differentiated; 4. Well differentiated, immature - embryonic form); 5 . Well differentiated, immature - fetal form; 6. Well differentiated, mature. End points of AFP staining shows maximum in the steps 3 and 4; AFP is absent in steps 1 and 6.

originate from the mother stem cells cells induced by the elements that regulate their division, would be promising for this pathology.

IGF-I is considered to play a principal roll in tumorigenesis [65] and especially in glioblastoma - the most common primary brain tumor in adults [77], with a prognosis for survivals below 1 year, and only in $5-10 \%$ cases below 2 years [78]. In this tumor, as well as in teratocarcinoma derived of PCC stem cells, the IGF-I and insulin increases proliferation by different signalling pathways, promoting cell growth of glioblastoma [79]. By the way, the clinical epidemiologic studies evidenced an increase mortality rate in patients treated with insulin [80], underlying the supplement data of signal transdution pathway of IGF-I playing a role in risk factor of the cancer development $[79,81]$. A serum level of IGF-I is higher in glioblastoma patients [82], and tumor tissues present an increased IGF-I and insulin receptors levels compared to normal tissue [83] inducing the proliferation, differentiation and migration of tumor cells $[83,84]$. The mechanism of mutation in p53 inducing up-regulation in IFG-I receptor, and for the same reason a survival of cancer cells, can play also a role [85]. 


\begin{tabular}{|c|c|c|c|}
\hline \multirow{2}{*}{\multicolumn{2}{|c|}{$\begin{array}{c}\text { GF Antisense } \\
\text { Arrest of translation }\end{array}$}} & \multicolumn{2}{|c|}{ GF Triple helix } \\
\hline & & \multicolumn{2}{|c|}{ Arrest of transcription } \\
\hline $\begin{array}{c}\text { (iF RNA } \\
\text { (antisense RNA } \\
\text { transcribed by vect }\end{array}$ & $\begin{array}{c}\text { GF RNA } \\
\text { Sense mRNA }\end{array}$ & $\begin{array}{c}\text { GF DNA } \\
\text { Sense Antisense }\end{array}$ & $\begin{array}{l}\text { GF RNA } \\
\text { ( } 23 \text { pb RNA } \\
\text { transcribed } \\
\text { by vector) }\end{array}$ \\
\hline 3 , & $5 \longrightarrow$ GF protcin & 5,3 , & poly A \\
\hline I & I & I :: I & I \\
\hline I & I & I :: I & I \\
\hline I & I & $\mathrm{I}:: \mathrm{I}$ & I \\
\hline 3 , & 5 , & 5,3, & cap 5', \\
\hline & & & poly A \\
\hline & & & \\
\hline & & & \\
\hline & & & \\
\hline & & 5 , & cap 5, \\
\hline & & & \\
\hline
\end{tabular}

Figure 4. Schema of Antisense and Triple helix technology to arrest Growth Factor, GF. In antisense technology the end result is the inhibition of GF mRNA (sense RNA) activity by binding to the antisense RNA. In GF triple helix technology, the oligopurine third strand (23bp) forms RNA-DNA triple helix with GF gene.

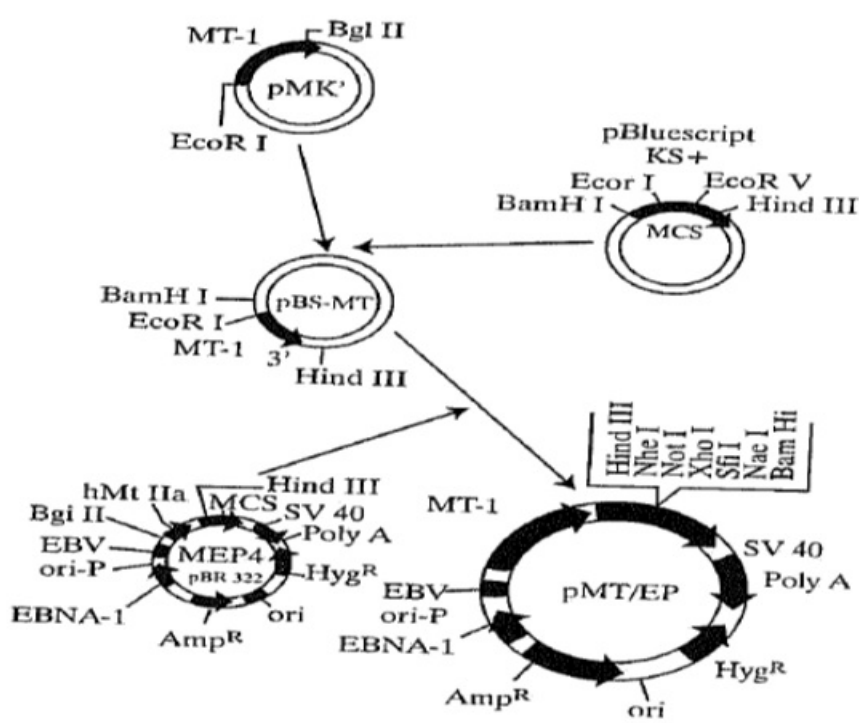

Figure 5. Schema of preparation of pMT/EP vector for IGF-I antisense and IGF-I triple helix technology.

New or proposed therapies of glioblastoma are based either on immune treatment or on immuno-gene strategies [86], including inhibitors [87], and the anti-gene strategy [66-70,88]. The last approach has permitted us to establish new and successful gene therapy strategies targeting glioma's growth factors and have now been introduced into clinical trials (the median survival of patients has reached 2 years, and in some cases 3 or 4 years) [89].

Other AS approaches targeting TGF-beta or VEGF, their receptors and their down stream transduction signaling elements [90-92], appear to offer hope for a promising solution. The recent neuro-oncology research underlines a focus on the role of the PI3K/AKT pathway in glial cells: the simultaneous arrest of at least two links either IGF-I or TGFbeta or VEGF and GS, of the pathway TK/PI3K/AKT/GSK3/ GS [92-94] seems to be in line for a future clinical gene therapy trial strategy for treatment of GBM.
Other recently introduced technologies include potentially useful siRNA [95,96] and miRNA (microRNA) [97]. The role of 21-23 mer double-stranded RNA (si RNA) in the silencing of genes is strongly similar to that of the TH DNA mechanism, which also involves 23 mer RNA [70]. As to miRNAs, they may play a fundamental role in tumorigenesis, controlling cell proliferation and apoptosis; in gliomas, the miRNA (microRNA-21) level has been reported to be elevated [98].

\section{New horizons: Stem cells of SNc and learning}

Synaptogenesis plays an important role in learning and memory. It takes a month to move from newly formed daughter stem cells to the integration of daughter cells in a brain circuit and connect with existing ones, forming synapses. In the process of synaptogenesis, the dendrites of one neuron are contacted with the axon of another neuron. Dendritic spines change their shape in minutes. In his article Fred Gage informs us: "Exercises, physical activity, experience, can regulate the rat of neurogenesis in the hippocampus, the subsistence of newborn stem cells neurons and their ability to integrate into the existing neuronal circuit "[56]. Henrieth van Praag has showed that a mouse exercised on a rotating ring can double the number of dividing stem cells in the hippocampus $[99,100]$.

Concerning the mechanism of memory, scientists investigate small molecules that can stimulate genes that produce growth factors. Another possibility is to use a gene therapy and cell transplantation. These technics could permit to increase a cellular production of growth factors by genetic manipulation followed by the implant of these cells
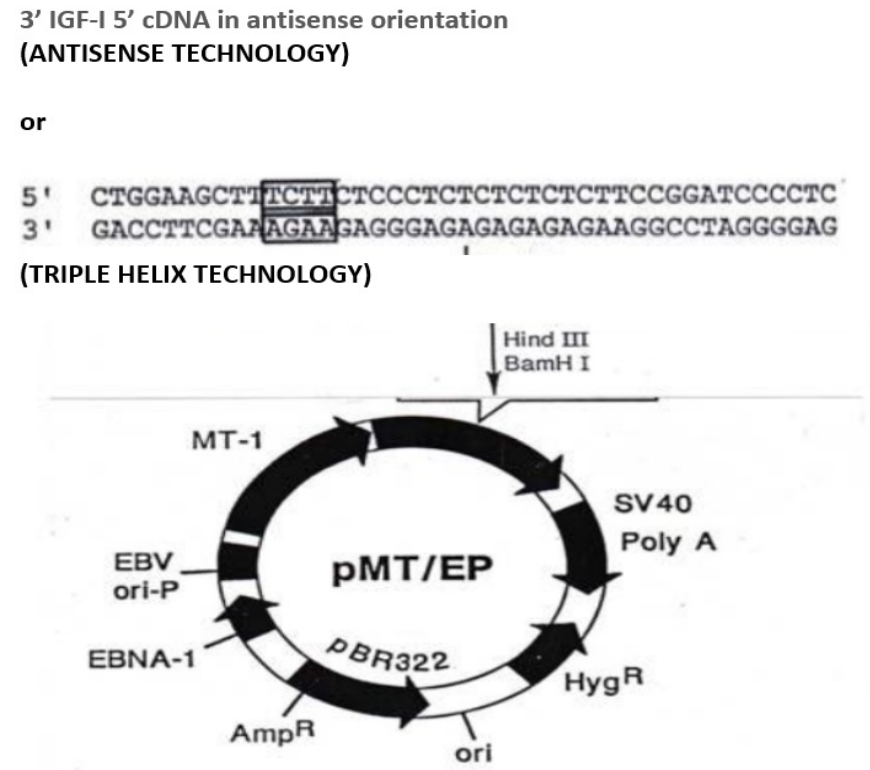

Figure 6. Construction of antisense and triple helix vectors. In antisense technology cDNA in antisense orientation is inserted: the episomal vector express antisens IGF-I RNA. In triple helix technology the 23 bp RNA prepared by PCR is inserted: the episomal vector express 23 bp RNA forming triple helix with genomic DNA as follows:

AGAAGAGGGAGAGAGAGAAGG -- oligopurin poli A 3' AGAA 5' cap

AGAAGAGGGAGAGAGAGAAGG

IIIIIIIIIIIIIIIIIIIIIIIIIIIIIIIIIIIII -- genomic DNA

TCTTCTCССТCTCТСТСТСТCC

***Hoogsteen bonds

III Watson-Crick bonds 
Tumor cells in vitro

IGF-I (+), expression of IGF-I mRNA and IGF-I (TK) receptor

Transfection $\$ Vector IGF-I antisens

Tumor transfected cells in vitro

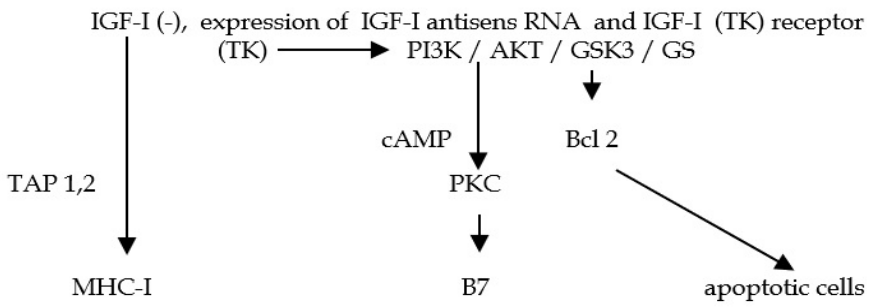

Figure 7. Mechanism of immunogene therapy. After transfection in vitro of stem cells PCC3 embryonal carcinoma cells, using Antisens IGF-I vector, the cells stop to synthesize IGF-I, and become immunogenic, expressing MHC-I and B7 antigens. One part of cells enter in apoptosis Celulas "antisentido" (anti IGF-I). The injection of these transfected cells into animal induce anti tumor immune response mediated by CD8 lymphocytes. [87,93]. Abreviaturas: TAP 1,2: transporter associated withantigen processing antigen); TK: tyrosine kinase; PI3K: phosphatidyinositol 3 kinase; PDK1: phosphoinositide-dependen kinase 1; AKT: PKB, protein kinase B; Bcl 2: key molecule of apoptose; GSK3: glycogene synthetase kinase 3; GS: glycogene synthetase; PKC: protein kinase C.
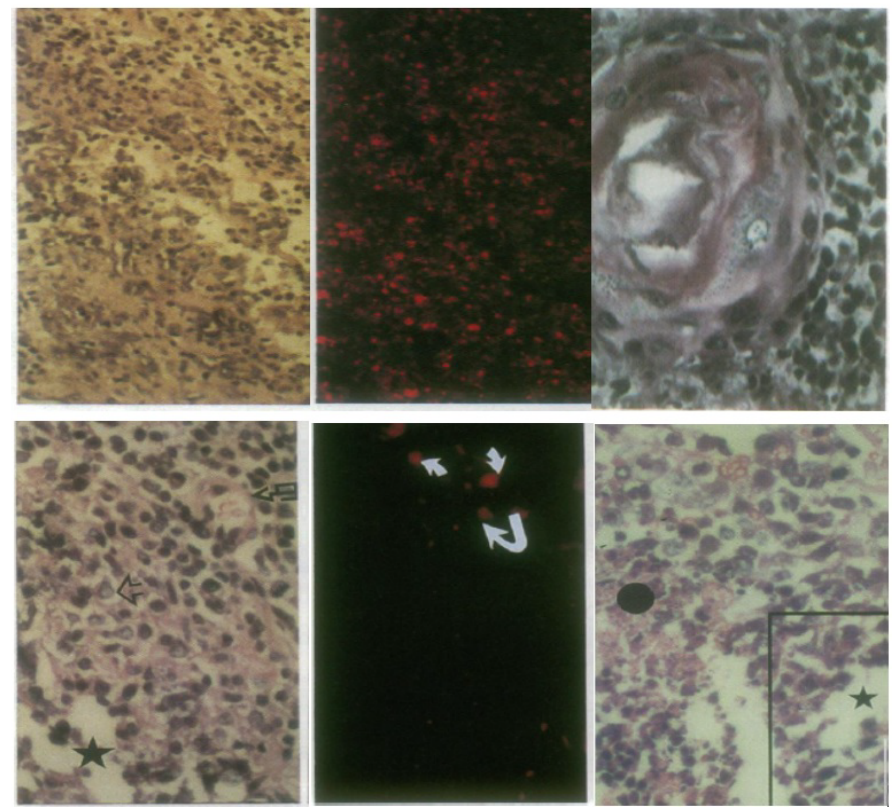

Figure 8. (Up) Lesions resulting from injection of PCC3 cells expressing antisense IGF-I RNA (left and middle) and antisense IGF-II (right) into 129 SV mice. (left) Lymphocyte infiltration, HE, x80; (middle) serial section stained with anti CD8 antibodies, x80. (right) Mature epidermoid structure accompanied by a sheet of dark neuroepithelial cells, HE, $\mathrm{x} 125$. (Down) Tumor regression induced by injection of antisense IGF-I expressing PCC3 transfected cells. (left) Teratocarcinoma 4 days following transfected PCC3 cells in hection, showing embryonal carcinoma cells (open arrow), neuroblastic cells arranged in pseudo rosettes (star), and nervous-system derived cells scattered about blood vessel (broken arrow), HE, x110. (middle) Serial section stained with anti CD8 antibodies, x110. (right) Teratocarcinoma 9 days following transfected cell injection, showing embryonal carcinoma cells and pseudo rosettes of neuroblastic cells (star), and disentegrating and necrotic tissue (black circle), HE, x110.

in a certain region of the brain. This possibility requires an ethical consideration: the growth factors could induce tumor development, and the transplanted cells could be out of control. That would be an acceptable risk in patients with Alzheimer's disease, but not in healthy ones.
Environment stimulates neurogenesis in the ventricles and the hippocampus, the migration of stem cells and neuronal precursors to the olfactory bulb. Then the stem cells 'travel' to specific sites within the brain where synaptogenesis will occur, participating in events that generate plasticity and capacity for self-regeneration and brain selfrepair. Ratey tells us that "aging is inevitable, a serious loss of memory is not" [101]. Several factors can delay the onset of memory impairment in Alzheimer's and senile dementia; there are, among others, following subjects in current research:the ingestion of antioxidants such as vitamin $\mathrm{E}$ and Celegeline, nonsteroidal anti-inflammatory drugs, Aspirin and Ibuprofen, vitamin B 12, ingestion of Carnitine. Ginkgo biloba has not been shown to have favorable effects on neurogenesis, but it can increase blood flow and cerebral oxygenation [16,56,99-106].

\section{Authorship and contributorship}

All authors (SJB, RS, AA, JJR, JT) contributed equally to the preparation of the manuscript. Authorship credit was based on 1) substantial contributions to conception, acquisition of data and interpretation of data; 2) revising the article critically for important intellectual content; 3 ) final approval of the version to be published; and 4) agreement to act as guarantor of the work

\section{Acknowledgements}

We would like to thank Mrs Annabelle Trojan (FUJNC University, Bogota) for the valuable discussion of results, and the correction of the final text.

\section{Funding information}

The authors received the support of the Society ICGT S.A.S. of Bogotá (President J. Trojan), and of the UNAB University of Bucaramanga (Dean J.J. Rey).

\section{Competing interests}

The authors declare that they have no competing financial or nonfinancial interests.

\section{References}

1. Alvarez - Buyllo A (2002) Subventricular zone. J Neurosci 22(03): 614-639.

2. D'Sa C, Duman RS (2002) Antidepressants and neuroplasticity. Bipolar Disord 4: 183194. [Crossref]

3. Sharma S, Vyas G, Gawarikar SB, Garg V, Rai MC, et al (2011). Stem cell transplantation: brief review and current status. J Indian Med Assoc 109(8): 579-581.

4. Hsu YC, Fuchs E (2012) A family business: stem cell progeny join the niche to regulate homeostasis. Nat Rev Mol Cell Biol 13: 103-114. [Crossref]

5. Nguyen LV, Vanner R, Dirks P, Eaves CJ (2012) Cancer stem cells: an evolving concept. Nat Rev Cancer 12(2):133-143.

6. Pino A, Fumagalli G, Bifari F, Decimo I (2017) New neurons in adult brain: distribution, molecular mechanisms and therapies. Biochem Pharmacol 141:4-22. [Crossref]

7. Alvarez-Buylla A, García-Verdugo JM (2002) Neurogenesis in adult subventricular zone. J Neurosci 22(3): 629-634. [Crossref]

8. Fiona Doetsch, Garcia-Verdugo JM, Alvarez-Buylla A (1997) Cellular composition and three-dimensional organization of the subventricular germinal zone in the adult mammalian brain. J Neurosci 17(13): 5048-5081. [Crossref]

9. Gebara E, Bonaguidi MA, Beckervordersandforth R, Sultan S, Udry F, et al (2016) Heterogeneity of Radial Glia-Like Cells in the Adult Hippocampus. Stem Cells 34 997-1010. [Crossref]

10. Mana MD, Kuo EY, Yilmaz ÖH (2017) Dietary Regulation of Adult Stem Cells. Cur Stem Cell Rep 3: 1-8. [Crossref]

11. Phillips C, Cristy (2017) Brain-derived neurotrophic factor, depression, and physical activity: Making the neuroplastic connection. Neural Plast 1 : 1-17. 
Bueno SJ (2018) Brain stem cells and IGF-I: implications in development, regeneration and cancer therapeutics

12. Sotthibundhu A, Phansuwan-Pujito P, Govitrapong P (2010) Melatonin increases proliferation of cultured neural stem cells obtained from adult mouse subventricular zone. J Pineal Res 49(3): 291-300.

13. Schlenska-Lange A, Knüpfer H, Lange TJ, Kiess W, Knüpfer M (2017) Cell proliferation and migration in glioblastoma multiforme cell lines are influenced by insulin-like growth factor I in vitro. Anticancer Res 28(2A): 1055-1060.

14. Trojan LA, Kopinski P, Wei MX, Ly A, Glogowska A, et al (2002) IGF-I: from diagnostic to triple-helix gene therapy of solid tumors. Acta Biochim Pol 49(4): 979-990.

15. Castrén M (2012) Neural stem cells. Results Probl Cell Differ 54: 33-40. [Crossref]

16. Sanberg PR, Eve DJ, Cruz LE, Borlongan CV (2012) Neurological disorders and the potential role for stem cells as a therapy. Br Med Bull 101: 163-181. [Crossref]

17. Altman J, Das GD (1965) Autoradiographic and histological evidence of postnatal hippocampal neurogenesis in rats. J Comp Neurol 124: 319-335. [Crossref]

18. Altman J (1969) Autoradiographic and histological studies of postnatal neurogenesis. J Comp Neurol 137(3):337-89.

19. Lim DA, Alvarez-Buylla A (2016) The adult ventricular-subventricular zone (V-SVZ) and olfactory bulb (OB) neurogenesis. Cold Spring Harb Perspect Biol 8(5): a018820.

20. Ortega F, Berninger B, Costa MR (2013) Primary culture and live imaging of adul neural stem cells and their progeny. In: Methods in molecular biology, Clifton, NY, p.1-11.

21. Rushing G, Ihrie RA (2016) Neural stem cell heterogeneity through time and space in the ventricular-subventricular zone. Front Biol 11(4): 261-284.

22. Zhao H, Alam A, San C-Y, Eguchi S, Chen Q, et al (2017) Molecular mechanisms of brain-derived neurotrophic factor in neuro- protection: Recent developments. Brain Res 1665: 1-21. [Crossref]

23. Kosaka K, Aika Y, Toida K, Heizmann CW, Hunziker W, et al (1995) Chemically defined neuron groups and their subpopulations in the glomerular layer of the rat main olfactory bulb. Neurosci Res 23(1):73-88.

24. Kempermann G, Song H, Gage FH (2015) Neurogenesis in the Adult Hippocampus. Cold Spring Harb Perspect Biol 7: a018812. [Crossref]

25. Song J, Olsen RHJ, Sun J, Ming G-L, Song H (2016) Neuronal circuitry mechanisms regulating adult mammalian neurogenesis. Cold Spring Harb Perspect Biol 8(8): a018937.

26. Bao H, Asrican B, Li W, Gu B, Wen Z, et al (2017) Long-range GABAergic inputs regulate Neural Stem Cell quiescence and control adult hippocampal neurogenesis. Cell Stem Cell 21(5): 604-617.e5.

27. Pardo J, Uriarte M, Cónsole GM, Reggiani PC, Outeiro TF, et al (2016) Insulin-like growth factor-I gene therapy increases hippocampal neurogenesis, astrocyte branching and improves spatial memory in female aging rats. Eur J Neurosci 44(4): 2120-2128. [Crossref]

28. Morel GR, León ML, Uriarte M, Reggiani PC, Goya RG (2017) Therapeutic potential of IGF-I on hippocampal neurogenesis and function during aging. Neurogenesis 4(1): e1259709.

29. Lugert S, Basak O, Knuckles P, Haussler U, Fabel K, et al (2017) Cell Stem Cell article quiescent and active hippocampal Neural Stem Cells with distinct morphologies respond selectively to physiological and pathological stimuli and aging. Stem Cell 6: 445-456.

30. Villeda SA, Luo J, Mosher KI, Zou B, Britschgi M, et al (2011) The ageing systemic milieu negatively regulates neurogenesis and cognitive function. Nature 477(7362): 90-94. [Crossref]

31. Lezi E, Burns JM, Swerdlow RH (2014) Effect of high-intensity exercise on aged mouse brain mitochondria, neurogenesis, and inflammation. Neurobiol Aging 35(11): 2574-258305. [Crossref]

32. Mastrorilli V, Scopa C, Saraulli D, Costanzi M, Scardigli R, et al (2017) Physical exercise rescues defective neural stem cells and neurogenesis in the adult subventricular zone of Btg1 knockout mice. Brain Struct Funct 222(6): 2855-2876.

33. Lorens-Martín M, Torres-Alemán I, Trejo JL (2010) Exercise modulates insulin-like growth factor 1-dependent and -independent effects on adult hippocampal neurogenesis and behaviour. Mol Cell Neurosci 44(2): 109-117.

34. Overall RW, Walker TL, Fischer TJ, Brandt MD, Kempermann G (2016) Different mechanisms must be considered to explain the increase in hippocampal neural precursor cell proliferation by physical activity. Front Neurosci 10: 362. [Crossref]
35. van Praag H (2008) Neurogenesis and exercise: past and future directions. Neuromolecular Med 10: 128-140. [Crossref]

36. So JH, Huang C, Ge M, Cai G, Zhang L, et al (2017) Intense exercise promotes adult hippocampal neurogenesis but not spatial discrimination. Front Cell Neurosci 11: 13.

37. Cirelli C (2009) The genetic and molecular regulation of sleep: from fruit flies to humans. Nat Rev Neurosci 10: 549-560. [Crossref]

38. Goshen I, Kreisel T, Ounallah-Saad H, Renbaum P, Zalzstein Y, et a (2007) A dual role for interleukin-1 in hippocampal-dependent memory processes. Psychoneuroendocrinology 32: 1106-1115. [Crossref]

39. Zhiguo Chen, Theo D, Palmer (2013) Differential roles of TNFR1 and TNFR2 signaling in adult hippocampal neurogenesis. Brain Behav Immun 30: 45-43.

40. Heese K (2017) Functional repertoire of interleukin-6 in the central nervous system review. Restor Neurol Neurosci 35(6): 693-701.

41. Yirmiya R, Goshen I (2011) Immune modulation of learning, memory, neural plasticity and neurogenesis. Brain Behav Immun 25(2): 181-213.

42. Lan X, Chen Q, Wang Y, Jia B, Sun L, Zheng J, et al (2012) TNF-a Affects Human Cortical Neural Progenitor Cell Differentiation through the Autocrine Secretion of Leukemia Inhibitory Factor. PLoS One 7(12).

43. Gonzalez-Perez O, Gutierrez-Fernandez F, Lopez-Virgen V, Collas-Aguilar J, Quinones-Hinojosa A, et al (2012) Immunological regulation of neurogenic niches in the adult brain. Neuroscie 226: 270-81. [Crossref]

44. Daughaday WH, Rotwein P (1989) Insulin-Like Growth Factors I and II. Peptide, messenger ribonucleic acid and gene structures, serum, and tissue Concentrations. Endocr Rev 10(1): 68-91.

45. Weiss YA (1998) Insulin-Like Growth Factor-I is a differentiation factor for postmitotic CNS Stem Cell-derived neuronal precursors: Distinct actions from those of brainderived neurotrophic factor. $J$ Neurosci 18(6): 2118-2128. [Crossref]

46. Yuan H, Chen R, Wu L, Chen Q, Hu A, et al (2015) The regulatory mechanism of neurogenesis by IGF-1 in adult mice. Mol Neurobiol 51(2): 512-522.

47. Ziegler AN, Levison SW, Wood TL (2015) Insulin and IGF receptor signalling in neural-stem-cell homeostasis. Nat Rev Endocrinol 11: 161-170. [Crossref]

48. Mir S, Cai W, Carlson SW, Saatman KE, Andres DA (2017) IGF-1 mediated neurogenesis involves a novel RIT1/Akt/Sox2 cascade. Sci Rep 7(1): 3283.

49. Huat T, Khan A, Pati S, Mustafa Z, Abdullah J, et al (2014) IGF-1 enhances cell proliferation and survival during early differentiation of mesenchymal stem cells to neural progenitor-like cells. BMC Neurosci 15(1): 91. [Crossref]

50. Supeno NE, Pati S, Hadi RA, Ghani ARI, Mustafa Z, et al (2013) IGF-1 acts as controlling switch for long-term proliferation and maintenance of EGF/FGF-responsive striatal neural Stem Cells. Int J Med Sci 10(5): 522-531. [Crossref]

51. Nieto-Estévez V, Oueslati-Morales CO, Li L, Pickel J, Morales AV. et al (2016) Brain Insulin-Like Growth Factor-I directs the transition from Stem Cells to mature neurons during postnatal/adult hippocampal neurogenesis. Stem Cells 34(8): 2194-2209.

52. Hurtado-Chong A, Yusta-Boyo MJ, Vergaño-Vera E, Bulfone A, de Pablo F, et al (2009) IGF-I promotes neuronal migration and positioning in the olfactory bulb and the exit of neuroblasts from the subventricular zone. Eur J Neurosci 30(5): 742-755.

53. McCurdy RD, Féron F, McGrath JJ, Mackay-Sim A (2005) Regulation of adul olfactory neurogenesis by insulin-like growth factor-I. Eur J Neurosci 22(7): 1581-1588.

54. Tang JJ, Podratz JL, Lange M, Scrable HJ, Jang M-H, et al (2017) Mechano growthfactor, a splice variant of IGF-1, promotes neurogenesis in the aging mouse brain. Mol Brain 10(1): 23. [Crossref]

55. Ming G-L, Song H (2011) Adult neurogenesis in the mammalian brain: Significant answers and significant questions. Neuron 70(4): 687-702.

56. Gage FH, Temple S (2013) Neuron perspective neural stem cells: Generating and regenerating the brain. Neuron 80(3):588-601.

57. Toda T, Gage FH (2017) Review: adult neurogenesis contributes to hippocampal plasticity. Cell Tissue Res.

58. Martino G, Pluchino S, Bonfanti L, Schwartz M (2011) Brain regeneration in physiology and pathology: the immune signature driving therapeutic plasticity of neural stem cells. Physiol Rev 91(4): 1281-1304.

59. Titomanlio L, Kavelaars A, Dalous J, Mani S, El Ghouzzi V, et al (2011) Stem cell therapy for neonatal brain injury: perspectives and challenges. Ann Neurol 70: 698712. [Crossref] 
60. Bonnamain V, Mathieux E, Thinard R, Thébault P, Nerrière-Daguin V, et al (2012) Expression of heme oxygenase-1 in neural stem/progenitor cells as a potential mechanism to evade host immune response. Stem Cells 30(10): 2342-53.

61. Trojan J, Uriel J (presented by F. Jacob) (1979). Intracellular localisation of alphafeprotein and serum albumin in the central nervous system of the rat during fetal and post natal development (in French). C R Acad Sci, Paris 289(15): 1157-1160.

62. Trojan J, Uriel J, Deugnier MA, Gaillard J (1984). Immunocytochemical quantitative study of alpha-fetoprotein in normal and neoplasic neural development. Dev Neurosci 6: 251-59.

63. 62. Kiess W, Lee L, Graham DE, Greenstein L, Tseng LY, et al (1989) Rechler, M.M. yRat C6 glial cells synthesize insulin-like growth factor I (IGF-I) and express IGF-I receptors and IGF-II/mannose 6-phosphate receptors. Endocrinol 124: 1727-1736.

64. Trojan J, Blossey BK., Johnson T, Rudin S., Tykocinski M, et al (1992). Loss of tumorogenicity of rat glioblastoma directed by episome-based antisense cDNA transcription of insulin-like growth factor I. Proc Natl Acad Sci USA 89(11): 4874- 4878.

65. Pollak MN, Schernhammer ES, Hankinson SE (2004) Insulin-like growth factors and neoplasia. Nat Rev Cancer 4: 505-518. [Crossref]

66. Rubenstein JL, Nicolas JF, Jacob F (1984) [Nonsense RNA: a tool for specifically inhibiting the expression of a gene in vivo]. CR Acad Sci III 299: 271-274. [Crossref]

67. Weintraub H, Izant J, Harland R (1985). Antisense RNA as a molecular tool for genetic analysis. Trends in Genetics 1(1): 23-25. http://dx.doi.org/10.1016/S0168- 9525

68. Green PJ, Pines O, Inouye M (1986) The role of antisense RNA in gene regulation. Annu Rev Biochem 55: 569-597. [Crossref]

69. Dervan PB (1992) Reagents for the site-specific cleavage of megabase DNA. Nature 359: 87-88. [Crossref]

70. Hélène C (1994) Control of oncogene expression by antisense nucleic acids. Eur $J$ Cancer 30A: 1721-1726.

71. Trojan J, Johnson TR, Rudin SD, Ilan Ju, Tykocinski ML et al (1993). Treatment and prevention of rat glioblastoma by immunogenic C6 cells expressing antisense Insulinlike Growth Factor I RNA. Science 259: 94-97.

72. Wikipedia - Free Encyclopedia, Gene therapy - History 1990s, updated 201773. Trojan J, Johnson T, Rudin S, Blossey B., Kelley, et al (1994). Gene therapy of murine teratocarcinoma: separate functions for insulin-like growth factors I and II in immunogenicity and differentiation. Proc Natl Acad Sci USA 91: 6088-6092.

73. François JC, Duc HT, Upegui-Gonzalez LC, Bedel C, Henin D, et al (2001) Alteration in tumorigenicity of embryonal carcinoma cells by IGF-I triple-helix induced changes in immunogenicity and apoptosis. Life Sci 68(3): 307-319

74. Trojan J1, Pan YX, Wei MX, Ly A, Shevelev A, et al (2012) Methodology for Anti-Gene Anti-IGF-I Therapy of Malignant Tumours. Chemother Res Pract 2012: 721873. [Crossref]

75. Trojan J, Briceño I (2013). IGF-I antisense and triple-helix gene therapy of glioblastoma. In: T. Lichtor "Evolution of the molecular biology of brain tumors and the therapeutic implications", Ed. InTech, Vienna, Riyeka, Vol. 5, pp 149-166.ISBN 980-953-307-74

76. Fisher PG, Buffler PA (2005) Malignant gliomas in 2005: where to GO from here? JAMA 293: 615-617.

77. DeAngelis LM1 (2001) Brain tumors. N Engl J Med 344: 114-123. [Crossref]

78. Trojan J, Anthony DD (2011) Antisense strategies in therapy of gliomas. Curr Signal Transd T6(3): 411-423.

79. Ranc K, Jørgensen ME, Friis S, Carstensen B (2014) Mortality after cancer among patients with diabetes mellitus: effect of diabetes duration and treatment. Diabetologia57(5): 927-934. [Crossref]

80. LeRoith D1, Roberts CT Jr (2003) The insulin-like growth factor system and cancer. Cancer Lett 195: 127-137. [Crossref]

81. Dmitrenko VV, Kavsan VM, Boyko OI, Rymar VI, Stepanenko AA, et al (2017) Expression of genes belonging to the IGF-system in glial tumors. Tsitol Genet 45(5): 41-57. [Crossref]

82. Merril MJ, Edwards NA (1990) Insulin-Like Growth Factor-I Receptors in human glial tumors. J Clin Endocrinol Metab 71(1): 199-209. [Crossref]

83. Resnicoff M, Burgaud J-L, Rotman HL, Abraham D, Baserga R (1995) Correlation between apoptosis, tumorigenesis, and levels of Insulin-like Growth Factor I Receptors1. Cancer Res 55: 3739-3741. [Crossref]

84. Girnita L, Girnita A, Brodin B, Xie Y, Nilsson G, et al (2000) Increased expression of insulin-like growth factor I receptor in malignant cells expressing aberrant p53: functional impact. Cancer Res 60(18): 5278-5283. [Crossref]
85. Kjaergaard J, Wang L, Kuriyama H, Shu S, Plautz GE (2005) Active immunotherapy For advanced intracranial murine tumors by using dendritic cell-tumor cell fusion vaccines. J Neurosurg 103: 156-164.

86. Trojan J, Cloix J-F, Ardourel M-Y, Chatel M, Anthony DD (2007) Insulin-like growth factor type 1 biology and targeting in malignant glioma. Neurosci 2007; 145: 795-811. [Crossref]

87. Hutterer M, Gunsilius E, Stockhammer G (2006) Molecular therapies for malignant glioma. Wien Med Wochenschr 156: 351-363. [Crossref]

88. Trojan J (2017) Brain - from development to neoplasia and gene therapy solution. Ed Lambert Academic Publishers, Saarbrucken, 2017/2018, pp 1 - 150, ISBN : 978- 620$2-08024-8$

89. Schlingensiepen KH, Fischer-Blass B, Schmaus S, Ludwig S (2008). Antisense therapeutics for tumor treatment: the TGF-beta2 inhibitor AP 12009 in clinical development against malignant tumors. Recent Results Cancer Res 177: 137-150.

90. Hau P, Jachimczak P, Bogdahn U (2009). Treatment of malignant gliomas with TGFbeta2 antisense oligonucleotides. Expert Rev Anticancer Ther 9(11): 1663-1674.

91. Pan Q, Luo X, Chegini N (2007) Blocking neuropilin-1 function has an additive effect with anti-VEGF to inhibit tumor growth. Cancer Cell 11(1): 53-67.

92. Beckner ME, Gobbel GT, Abounader R, et al (2005) Glycolytic glioma cells with Active glycogen synthase are sensitive to PTEN and inhibitors of PI3K and gluconeogenesis. Lab Invest 85:1457-1470. [Crossref]

93. Beckner ME, Gobbel GT, Abounader R, Burovic F, Agostino NR, et al (2005) Glycolytic glioma cells with active glycogen synthase are sensitive to PTEN and inhibitors of PI3K and gluconeogenesis. Lab Invest 85: 1457-1470. [Crossref]

94. Premkumar DR, Arnold B, Jane EP, Pollack IF (2006) Synergistic interaction between $17 \mathrm{AAG}$ and phosphatidylinositol 3-kinase inhibition in human malignant glioma cells. Mol Carcinogene 45: 47-59. [Crossref]

95. Boado RJ (2005) RNA interference and nonviral targeted gene therapy of experimental brain cancer. NeuroRx 2(1): 139-150. [Crossref]

96. Pai SI, Lin YY, Macaes B, Meneshian A, Hung CF, et al (2006) Prospects of RNA interference therapy for cancer. Gene Ther 13: 464-477. [Crossref]

97. Berezikov E1, Thuemmler F, van Laake LW, Kondova I, Bontrop R, et al (2006) Diversity of microRNAs in human and chimpanzee brain. Nat Genet 38: 1375-1377. [Crossref]

98. Corsten MF, Miranda R, Kasmieh R, Krishevsky AM, Weisslederer R, et al (2007) MicroRNA-21 knockdown disrupts glioma growth in vivo and displays synergistic cytotoxicity with neural precursor cell delivered S-TRAIL in human gliomas. Cancer Res 67(19): 8994-9000. [Crossref]

99. Moon HY, Becke A, Berron D, Becker B, Sah N, et al (2016) Running-induced systemic Cathepsin B secretion is associated with memory function. Cell Metab 24(2): 332-340. [Crossref]

100. Vivar C, Peterson BD, van Praag H (2016) Running rewires the neuronal network of adult-born dentate granule cells. Neuroimage 131: 29-41. [Crossref]

101. Ratey JJ (2002) Brain: Manual of instructions (in Spanish). Ed. Mondadori Barcelona, p. 461. ISBN: 84-397-0914-5

102. Nottebohm F (2002) Why are some neurons replaced in adult brain? J Neurosci 22: 624-628. [Crossref]

103. Kokaia Z, Lindwall O (2003) Neurogenia after ischaemic brain insults. Curr Opinion Neurobiol 13(1): 127-132.

104. Bissonnette CJ, Lyass L, Bhattacharyya BJ, Belmadani A, Miller RJ, et al (2011) The controlled generation of functional basal forebrain cholinergic neurons from human embryonic. Stem Cells 29(5): 802-811. [Crossref]

105. Vaccarino FM, Stevens HE, Kocabas A, Palejev D, Szekely A, et al (2011) Induced pluripotent stem cells: a new tool to confront the challenge of neuropsychiatric disorders. Neuropharmacol 60(7-8): 1355-1363.

106. Robinton DA, Daley GQ (2012) The promise of induced pluripotent stem cells in research and therapy. Nature 481: 295-305. [Crossref]

Copyright: (C)2018 Bueno SJ. This is an open-access article distributed under the terms of the Creative Commons Attribution License, which permits unrestricted use, distribution, and reproduction in any medium, provided the original author and source are credited. 